\title{
Impact of aquatic exercise on persons with kidney disease: a systematic review and meta-analysis
}

\author{
David Rodríguez Rey', Miguel Adriano Sanchez-Lastra², Carlos Ayán Pérez ${ }^{3}$ \\ 'Universidad de Vigo. ${ }^{2}$ Healthy-Fit Research Group. Departamento de Didácticas Especiales. Universidad de Vigo. ${ }^{3}$ Well-Move Research Group. Departamento de Didácticas \\ Especiales. Universidad de Vigo
}

doi: 10.18176/archmeddeporte.0008

Received: 02/11/2019

Key words:

Aquatic exercise. Chronic kidney disease. Review. Meta-analysis.
Accepted: 27/03/2020

\section{Summary}

Objective: Analyze the scientific evidence on the effects that aquatic physical exercise has on people with chronic kidney disease (CKD).

Material and method: A systematic review was carried out following the checklist Preferred Reporting Items for Systematic review and Meta-Analysis Protocols, with the objective of locating the largest number of investigations that aimed to identify the effects of the practice of aquatic physical exercise in people with ERC. A search of the PubMed, PEDro, Scopus and Cochrane databases were carried out until March 2019, using the PEDro, CERT, MINORS and NIH scales to determine the methodological quality of the same.

Results: Five investigations were located, two of them were randomized control trials, another two studies comparatives and one was uncontrolled. The mean score and the median obtained after applying PEDro scale were 4 and 4 respectively. All the interventions proposed aerobic exercise programs, being generally of short duration and highly supervised, without any adverse effects arising from their practice. In a large part of the studies, significant effects were observed in physical condition, physiological parameters and quality of life, to a lesser extent. The practice of exercise had no significant impact on either the activity of the disease or the perceived pain in patients.

Conclusions: Practice of aquatic exercise is beneficial in people with ERC. More longitudinal studies are needed to assess the impact of aquatic exercises as well as its effect and quality of life in long term.

\section{Efectos del ejercicio acuático en personas con enfermedad renal: revisión sistemática y metaanálisis}

\section{Resumen}

Objetivo: Analizar la evidencia científica existente sobre los efectos que el ejercicio físico acuatico tiene en personas con enfermedad renal crónica (ERC).

Material y método: Se realizó una revisión sistemática siguiendo la lista de verificación Preferred Reporting Items for Systematic review and Meta-Analysis Protocols, con el objetivo de localizar el mayor número de investigaciones que tuviesen como objetivo identificar los efectos de la práctica de ejercicio físico acuático en personas con ERC. Se realizó una búsqueda en las bases de datos PubMed, PEDro, Scopus y Cochrane, hasta marzo de 2019, empleándose las escalas PEDro, CERT, MINORS y NIH para determinar la calidad metodológica de las mismas.

Resultados: Se localizaron cinco investigaciones, dos fueron estudios aleatorizados controlados, dos estudios comparativos y uno no controlado. La puntuación media y la mediana obtenida tras aplicar la escala PEDro fue de 4 y de 4 respectivamente. Todas las intervenciones plantearon programas de ejercicio aeróbico, siendo por lo general de corta duración y altamente supervisadas, sin que se registraran efectos adversos derivados de su práctica. En gran parte de los estudios, se observaron

Palabras clave: Ejercicio acuático. Enfermedad renal crónica. Revisión. Metá-análisis. efectos significativos en la condición física, parámetros fisiológicos y la calidad de vida, en menor medida. La práctica de ejercicio no tuvo impacto significativo ni en la actividad de la enfermedad ni en el dolor percibido en los pacientes.

Conclusiones: La práctica de ejercicio físico acuático es beneficiosa para las personas con ERC. Son necesarios estudios longitudinales que valoren el impacto de programas de ejercicio, así como su efecto sobre la calidad de vida a largo plazo. 


\section{Introduction}

Chronic kidney disease (CKD) is a health problem of particular importance to society ${ }^{1,2}$. CKD is defined as a disease in which there is a decreased functioning of the kidneys, expressed in values of $\mathrm{FG}<60$ $\mathrm{ml} / \mathrm{min} / 1.73 \mathrm{~m}^{2}$ or with damage persisting for three months or more. In Spain, the prevalence of CKD is $9.16 \%$ in the adult population aged over 20 years and increases to $23.7 \%$ in adults aged over 65 years ${ }^{3}$ with the main reasons for developing this condition being ageing itself, arterial hypertension (AHT), diabetes and vascular disease ${ }^{4}$. On the other hand, risk situations that increase the probability of CKD encompass smoking, diabetes, cardiovascular disease, family history, being an African American, and anaemia among others².

In terms of cost, the Spanish state spends around EUR 800 million as stated in the SEN-semFYC (Spanish Society of Nephrology - Spanish Society of Family and Community Medicine) Consensus Document on chronic disease ${ }^{5}$. A large part of the budget is allocated to treatment, although there is no definitive solution, the most common palliative care is dialysis 6 . The disease, together with the appropriate treatment may have adverse effects, including a lower quality of life ${ }^{7,8}$. Moreover, this pathology is frequently associated with other diagnoses, such as a reduction in bone density ${ }^{9}$, cardiovascular risk ${ }^{10}$, hypertension and type II diabetes ${ }^{11}$.

Given that there is no definitive treatment for CKD, exercise stands as an aid to prevention and to the improvement of those aspects affected by pain. It is known that patients undergoing haemodialysis show hypertension or anaemia, lowering their quality of life. Exercise is therefore considered to be an option for slowing down the disease ${ }^{12,13}$. In turn, the association between physical inactivity and mortality has been studied by a number of authors in earlier investigations, in which they indicate the high importance of physical exercise as a means to reduce the mortality rate in persons with kidney disease ${ }^{14,15}$.

In most of the studies, aerobic or strength exercises were performed $^{16,17}$, in a land-based environment in which gravity has a negative effect on the patient's physical abilities. Together with this, a number of problems can be found, including protocol assistance and adherence. The reasons are manifold, ranging from inability to go to the centre due to illness, admission to hospital or lack of transport ${ }^{18}$. On the other hand, physical factors also come into play, such as a limited range of movement, difficulty in getting around, lack of physical strength or fear of falling over, all indicating that this environment is not ideal for working with this population ${ }^{19}$.

Taking the above into account, aquatic exercise stands as an interesting alternative. Water offers a pleasant sensation and, thanks to its buoyancy, it is possible to take regular exercise and to conduct dynamic and motivating training programmes. In fact, aquatic exercise has been used in pathologies in which the patient's mobility and physical condition are seriously affected ${ }^{20}$.

It would therefore appear necessary to determine the impact of aquatic exercise programmes on persons with CKD and to provide guidelines for the prescription and control of such programmes. This information would facilitate the task of those rehabilitation professionals who are treating this population. This objective can be achieved by making systematic reviews in order to synthesize the scientific evidence available on a topic and to offer a critical interpretation of the quality and validity of such evidence.

The purpose of this investigation is therefore to conduct a systematic review of any existing investigations whose objective was to analyse the impact of aquatic exercise on persons with CKD.

\section{Material and method}

A systematic review was designed, based on the Preferred Reporting Items for Systematic review and Meta-Analysis Protocols (PRISMA-P) checklist, which is recommended for studies of this type ${ }^{21}$.

\section{Search strategy}

The search strategy was designed to find the greatest number of investigations whose objective was to identify the effects of aquatic exercise on persons with renal failure. For this purpose, a search was made with no time limit in the databases of PubMed, PEDro, Scopus and Cochrane, up to March 2019, combining the keywords and Boolean Operators as follows: "Kidney Disease" OR "Dialysis" OR "Renal Failure" AND "Water Based Exercise" OR "Aquatic Exercise"The search was repeated in May 2019, including the "Dialnet" database in order to update the results of the search and to locate any possible investigations in Spanish (Figure 1).

The search excluded all investigations that: a) included a sample comprising participants with different diseases and that did not provide separate information for persons with renal insufficiency; b) did not describe the physical training programme performed; $c$ ) analysed the effects of a single physical exercise session; d) used aquatic exercise in combination with other rehabilitation therapies; e) were written in a language other than Spanish, Portuguese or English.

\section{Selection procedure}

The information included in the title and/or abstract of each of the studies identified by the search strategy was screened independently, classifying the studies either as "valid (a priori)" or "not valid" based on the aforementioned selection criteria. Those studies whose title or abstract did not provide sufficient information to decide on their inclusion/exclusion were initially considered to be "valid (a priori)". Once this initial selection stage had been completed, both authors compared their respective classifications in order to reach a consensus. For any doubts as to whether a particular study should be considered as "valid (a priori)" or "not valid", the opinion of the supervising professor was requested. The next step was to read the full text of the studies finally classified as "valid (a priori)". 
Figure 1. Diagram summarising the search.

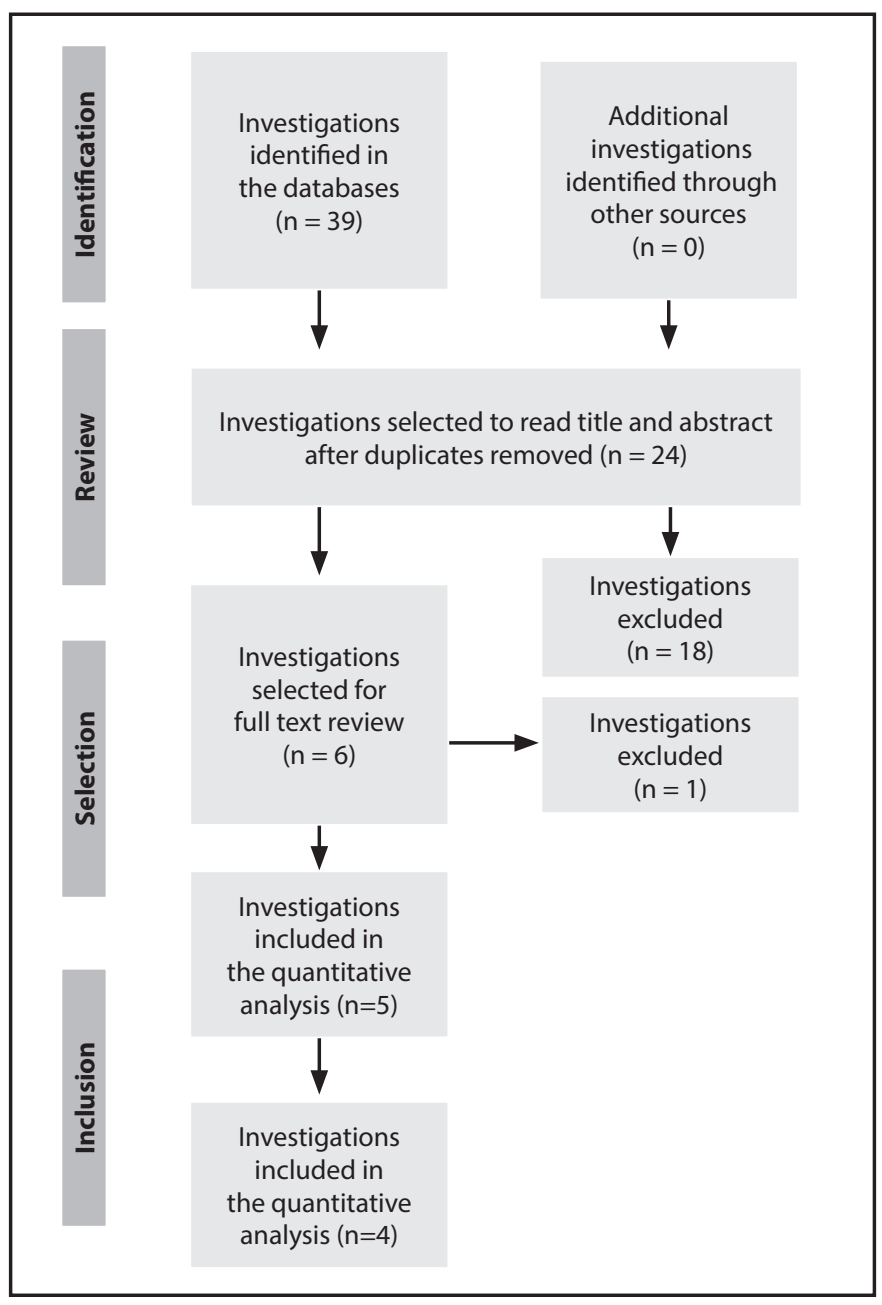

\section{Data extraction}

The information extracted from the "valid" studies was made by reading the studies, making it possible to independently identify and organise the relevant data in evidence tables. For each study, the following was considered: design type; sample characteristics; aquatic exercise programme; study variables; the respective evaluation tools; and the most significant results described in the investigation. The data extraction procedure was not blinded to the names of the authors of the studies selected nor to the names of the journals in which the studies were published.

\section{Evaluation of the methodological quality}

LThe methodological quality of the studies considered to be randomised controlled clinical trials (CKD) was determined through the use of the PEDro scale ${ }^{22}$.

The PEDro scale is a list of eleven criteria or points. The first one is not added to the total, the other ten are used to assess each article and to rate its methodological quality. The quality of the investigations was either taken directly from the PEDro database or directly assessed by the author of this study, for those investigations with no prior assessment

The total score obtained served to differentiate the quality of the investigations between high ( 6 or more points) or low (5 or less points) ${ }^{23}$ For the comparative investigations, the "MINORS"24 methodological index for non-randomised studies was used for the evaluation. The MINORS scale is a list containing 8 key points that is extended to 12 points for comparative studies. Each section is rated with a score from 0 to 2 , based on the quality obtained for each point. An acceptable score would be half the total points of the evaluation (8 or 12 depending on the type of study). For the full articles, the Consensus on Exercise Reporting Template (CERT) scale was used. This scale contains the minimum and sufficient recommendations to conduct an effective intervention ${ }^{25}$. The scale has a list of 16 points and the scores vary from 1 to 19, considering a score of less than 9 to be low quality and a score of 9 or more to be good quality. For those articles with a single pre-post intervention group, the Quality Assessment Tool for Before-After (Pre-post) Studies With No Control Group (NIH) was used, whereby the reviewer is the one to decide on the reliability of the study.

\section{Meta-analysis}

A meta-analysis was made of those studies that, including an intervention group and a comparison group, provided information on the effect of the aquatic programme using similar variables in at least two investigations.

To do so, the standardised mean differences (SMD) were calculated and the confidence interval $(\mathrm{Cl})$ of 95\% to measure the changes in the pre- and post-intervention control group, a comparison was also made across each variable. The SMD is the mean divided by the standard deviation (SD). This was calculated by taking the sizes of the samples of the pre- and post-intervention test groups for physical condition and blood, together with their means and their standard deviations for each one of the variables. Higgins et $a^{26}$. To obtain the combined effects, a fixed effects model was made ${ }^{27}$, selecting the most suitable models for each analysis in relation to the level of heterogeneity. The analysis used effects diagrams showing SMD and Cl of 95\%, serving to compare the effects between pre- and post-intervention control groups. The SMD is significant when $95 \%$ of its $\mathrm{Cl}$ excludes zero, while the SMD values of less than \pm 0.2 , or ranges between \pm 0.2 to 0.8 , or greater than \pm 0.8 indicate the existence of a small, medium or large effect respectively. All the analyses were made with the Comprehensive Meta-Analysis version 2.2.064.

\section{Results}

\section{Designs and samples}

A total of 39 articles were located from the search. After reading the title, 24 articles were initially selected. Of these, 18 articles were 
rejected due to the fact that their subject matter did not meet the criteria, leaving a total of 6 articles. After reading the full text of the articles, 5 studies were selected to make this present study (2 studies with randomized clinical trials, 1 study with no control group, and 2 comparative studies). A total of 119 participants were included (62.2\% male and $37.8 \%$ female) with a mean age of $50.1 \pm 12.6$ years and a disease duration of between 3 months and 42 months (0.253.5 years).

\section{Methodological quality}

The 2 randomised clinical trial articles were both given a score of 4 points (Table 1) $)^{28,29}$. The two comparative studies ${ }^{30,31}$ obtained a score of 17 and 20 points respectively (Table 2). The methodological quality of the study with no control group32 was considered to be good (Table 3). The quality with which the characteristics of the studies were detailed was considered to be low for articles ${ }^{28,29-32}$ based on the CERT scale (Table 4).

Table 1. Methodological quality of the randomised controlled studies (PEDro Scale)

\begin{tabular}{|c|c|c|}
\hline Criterion & $\begin{array}{c}\text { Petchter et al. } \\
2014{ }^{28}\end{array}$ & $\begin{array}{c}\text { Anastasia et al. } \\
2016^{29}\end{array}$ \\
\hline 1. Random allocation & 1 & 1 \\
\hline 2. Concealed allocation & 0 & 0 \\
\hline 3. Comparison of baseline data & 1 & 1 \\
\hline 4. Blinding of subjects & 0 & 0 \\
\hline 5. Blinding of therapists & 0 & 0 \\
\hline 6. Blinding of assessors & 0 & 0 \\
\hline 7. Outcome $85 \%$ subjects & 0 & 0 \\
\hline 8. Intention to treat analysis & 0 & 1 \\
\hline 9. Comparative analysis of groups & 1 & 1 \\
\hline 10. Estimate and variability points & 1 & 0 \\
\hline Total score & $4 / 10$ & $4 / 10$ \\
\hline
\end{tabular}

\section{Interventions}

All the physical activity programmes were conducted in shallow pools with a water temperature of between 32 and 24 degrees. The duration of the interventions ranged from 12 to 16 weeks, with sessions of between 30 to 60 minutes and with a frequency of between 1 to 3

Table 3. Methodological quality of the study with no control group (NHLBI Scale).

\begin{tabular}{ll}
\hline Criterion & Dziubek et al. $\mathbf{2 0 1 5}^{\mathbf{3 2}}$ \\
\hline $\begin{array}{l}\text { 1. Is the study objective clearly stated? } \\
\text { 2. Clear selection criteria }\end{array}$ & Yes \\
$\begin{array}{l}\text { 3. Are the participants in this study representative } \\
\text { of those that would be selected to replicate the }\end{array}$ & Yes \\
intervention? & \\
$\begin{array}{l}\text { 4. Did those participants who met the criterion } \\
\text { complete the study? }\end{array}$ & Yes \\
$\begin{array}{l}\text { 5.Was the sample sufficiently large to provide } \\
\text { significant results? }\end{array}$ & Yes \\
$\begin{array}{l}\text { 6. Was the intervention clearly described and } \\
\text { applied to the entire sample? }\end{array}$ & Yes \\
$\begin{array}{l}\text { 7. Were the measures of the variables clearly defined, } \\
\text { valid, replicable and consistently assessed? }\end{array}$ & Yes \\
$\begin{array}{l}\text { 8. Were the persons assessed blinded to the } \\
\text { interventions of the participants' variables? }\end{array}$ & NR \\
$\begin{array}{l}\text { 9. Was the drop-out rate of the initial group less than } \\
\text { 20\%? Was this 20\% accounted for in the analysis? }\end{array}$ & Yes \\
$\begin{array}{l}\text { 10. Were changes shown in the measures of the } \\
\text { variables before and after the intervention? }\end{array}$ & Yes \\
$\begin{array}{l}\text { Did the statistical tests give a p-value? } \\
\text { 11. Were the variables collected at different times } \\
\text { before the intervention and after the intervention? }\end{array}$ & NR \\
$\begin{array}{l}\text { 12. Did the statistical analysis determine } \\
\text { individually and at a group level the effect of } \\
\text { the intervention? }\end{array}$ & Yes \\
Quality score & \\
\hline
\end{tabular}

Table 2. Methodological quality of the comparative studies (MINORS Scale).

\begin{tabular}{|c|c|c|c|c|c|c|c|c|c|c|c|c|c|}
\hline Study & $\begin{array}{c}1 \\
\text { Clearly } \\
\text { stated } \\
\text { aim }\end{array}$ & $\begin{array}{c}2 \\
\text { Inclusion } \\
\text { of con- } \\
\text { secutive } \\
\text { patients }\end{array}$ & $\begin{array}{c}3 \\
\text { Pros- } \\
\text { pective } \\
\text { collection } \\
\text { of data }\end{array}$ & $\begin{array}{c}4 \\
\text { Evalua- } \\
\text { tions ap- } \\
\text { propriate } \\
\text { to study } \\
\text { aim }\end{array}$ & $\begin{array}{c}5 \\
\text { Unbiased } \\
\text { evalua- } \\
\text { tions } \\
\text { made }\end{array}$ & $\begin{array}{c}6 \\
\text { Follow-up } \\
\text { period } \\
\text { appro- } \\
\text { priate } \\
\text { to study } \\
\text { aim }\end{array}$ & $\begin{array}{c}7 \\
\text { Loss rate } \\
\text { in follow- } \\
\text { up less } \\
\text { than } 5 \%\end{array}$ & $\begin{array}{c}8 \\
\text { Pros- } \\
\text { pective } \\
\text { estimate } \\
\text { of sample } \\
\text { size }\end{array}$ & $\begin{array}{c}9 \\
\text { Adequate } \\
\text { control } \\
\text { group }\end{array}$ & $\begin{array}{c}10 \\
\text { Simul- } \\
\text { taneous } \\
\text { groups }\end{array}$ & $\begin{array}{c}11 \\
\text { Homo- } \\
\text { geneous } \\
\text { baseline } \\
\text { groups }\end{array}$ & $\begin{array}{l}12 \\
\text { Adequate } \\
\text { statistical } \\
\text { analysis }\end{array}$ & SCORE \\
\hline $\begin{array}{l}\text { Petcher } \\
\text { et al. } \\
2003 a^{30}\end{array}$ & 2 & 2 & 1 & 2 & 0 & 0 & 2 & 2 & 1 & 2 & 2 & 1 & $17 / 24$ \\
\hline $\begin{array}{l}\text { Petcher } \\
\text { et al, } \\
2003 b^{31}\end{array}$ & 2 & 1 & 2 & 2 & 0 & 2 & 2 & 2 & 2 & 2 & 1 & 2 & $20 / 24$ \\
\hline
\end{tabular}


Table 4. Quality of the information reported in relation to the characteristics of the proposed intervention (CERT Scale)

\begin{tabular}{|c|c|c|c|c|c|}
\hline Study & $\begin{array}{c}\text { Petchter et al. } \\
2003 a^{30}\end{array}$ & $\begin{array}{c}\text { Petchter et al. } \\
2003 b^{31}\end{array}$ & $\begin{array}{c}\text { Petchter et al. } \\
2014^{28}\end{array}$ & $\begin{array}{c}\text { Anastasia et al. } \\
2015^{29}\end{array}$ & $\begin{array}{c}\text { Dziubek et al. } \\
2015^{32}\end{array}$ \\
\hline 1. Sports equipment & 1 & 0 & 0 & 1 & 1 \\
\hline 2 Instructor's experience & 0 & 1 & 1 & 1 & 0 \\
\hline 3. Individual or group exercise & 1 & 1 & 1 & 1 & 1 \\
\hline 4. Supervision mechanism & 0 & 1 & 1 & 1 & 1 \\
\hline 5. Adherence to exercise & 0 & 0 & 0 & 1 & 0 \\
\hline 6. Motivation strategies & 0 & 0 & 0 & 0 & 0 \\
\hline 7 a. Determining progression & 1 & 1 & 1 & 1 & 1 \\
\hline 7b. Progression of exercise & 1 & 1 & 1 & 1 & 1 \\
\hline 8. Description of the exercise & 0 & 0 & 0 & 0 & 0 \\
\hline 9. Exercise at home & 0 & 0 & 0 & 0 & 0 \\
\hline 10. Non-exercise components & 0 & 0 & 0 & 0 & 0 \\
\hline 11. Adverse events & 0 & 0 & 0 & 1 & 1 \\
\hline 12. Setting & 1 & 0 & 0 & 0 & 1 \\
\hline 13. Intervention & 0 & 0 & 0 & 0 & 0 \\
\hline 14a. Generic/tailored exercise & 0 & 0 & 0 & 0 & 0 \\
\hline 14b. How was it tailored? & 0 & 0 & 0 & 0 & 0 \\
\hline 15. Starting level & 1 & 1 & 1 & 1 & 1 \\
\hline 16a. Adherence to programme & 0 & 0 & 0 & 0 & 0 \\
\hline 16b. Success of programme & 1 & 0 & 0 & 0 & 1 \\
\hline Points/19 & $7 / 19$ & $6 / 19$ & $6 / 19$ & $9 / 19$ & $8 / 19$ \\
\hline
\end{tabular}

days/week ${ }^{28-32}$. All studies were based on aerobic resistance exercises ${ }^{28-32}$. There were no reports of drop-outs or adverse effects resulting from the intervention.

\section{Effects of the programmes}

The studies analysed the effects of the aquatic programmes on physiological variables related to the physical condition. The main findings are summarised below and are also shown in Table 5.

\section{Physiological effects}

Two studies analysed the effects of the programme on physiological parameters ${ }^{30,31}$ finding significant improvements in systolic and diastolic pressures, as well as in different renal markers.

\section{Physical condition}

Four investigations provided information on the effects of the programme on different aspects of physical condition. Two found improvements in aerobic capacity ${ }^{30,31}$. Two in strength and flexibility ${ }^{32,29}$.

\section{Quality of life}

Only one investigation ${ }^{29}$ included quality of life as a study variable, finding that aquatic exercise exerted a positive impact on this.

\section{Results of the meta-analysis}

The meta-analysis conducted on the physiological variables ${ }^{30,31}$ $(n=2)$ (Figure 2) showed a significantly high statistical effect for cysteine $(\mathrm{SMD}=1.84,95 \% \mathrm{Cl}-1.06-2.62)$, diastolic pressure $(\mathrm{SMD}=1.23,95 \%$ $\mathrm{Cl}-0.66-1.93)$ and systolic pressure $(S M D=1.43,95 \% \mathrm{Cl}-0.76-2.11)$ with positive significance and high heterogeneity $(P=0.01>; P=0.01>$ $P=0.01>; P=0.05>; 12=76.9 \%)$.

The meta-analysis of the physical condition variables ${ }^{32,29}(n=2)$ (Figure 3) showed a significantly high statistical effect for cardiorespiratory capacity $(\mathrm{SMD}=0.61,95 \% \mathrm{Cl}-0.09-1.12 ; \mathrm{SMD}=0.71,95 \% \mathrm{Cl}-0.20$ - 1.29), strength (SMD $=0.93,95 \% \mathrm{Cl}-0.04-1.39)$, flexibility and balance $(\mathrm{SMD}=0.57,95 \% \mathrm{Cl}-0.12-0.63)$ with a significance level and high heterogeneity $(P=0.01>; P=0.01>; P=0.05>; \mid 2=67.1 \%)$. 
Figure 2. Meta-analysis - physiological variables.

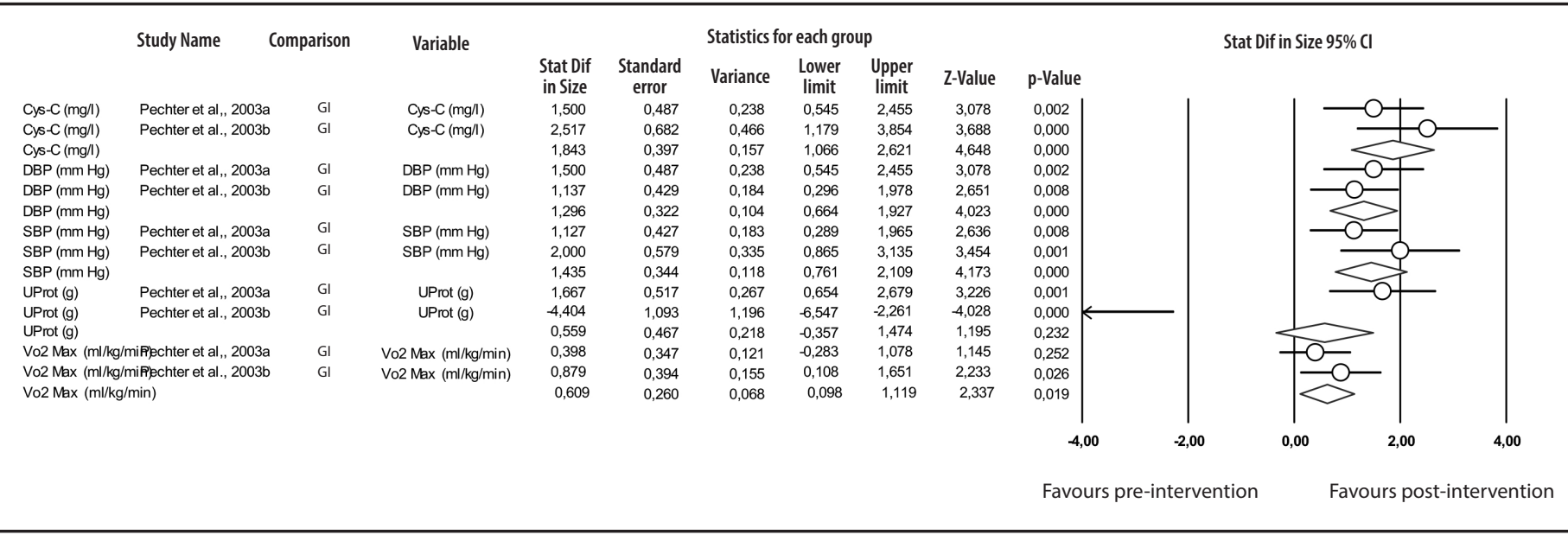

Table 5. Results of the articles analysed.

\begin{tabular}{|c|c|c|c|c|c|}
\hline Authors (year) & Objective & Participants & Intervention & Variables (test) & $\begin{array}{l}\text { Significant results } \\
(p<0.05) .\end{array}$ \\
\hline $\begin{array}{l}\text { Dziubek et al. } \\
2015^{32}\end{array}$ & $\begin{array}{l}\text { The study objective was } \\
\text { to measure the impact of } \\
\text { a 3-month programme of } \\
\text { physical activity in an aquatic } \\
\text { environment on patients } \\
\text { with renal disease and } \\
\text { the effect on the physical } \\
\text { function of the knee joint } \\
\text { muscles. }\end{array}$ & $\begin{array}{l}\text { Sample ( } \mathrm{n} ; \% \text { men/women): } \\
n=20 \text { ( } 16 \text { women and } \\
4 \text { men) } \\
\text { Distribution and age: } \\
\text { Mean group age } 64.2 \pm 13.1 \\
\text { years } \\
\text { T diagnosed (years): } \\
3.5 \pm 0.5 \text { years }\end{array}$ & $\begin{array}{l}\text { Duration: } 12 \text { weeks } \\
\text { IG (intervention group): } \\
\text { Frequency: } 1 \text { day/week } \\
\text { Duration: } 60 \text { min. } \\
\text { Type of exercise: } \\
\text { Aquatic exercise. } \\
\text { Intensity: Non-specific. }\end{array}$ & $\begin{array}{l}\text { Physical fitness: Fullerton Functional } \\
\text { Fitness Test by Rikli and Jones } \\
\text { (Senior Fitness Test): } \\
\text { - Eight foot up and go } \\
\text { - Arm curl } \\
\text { - Chair stand } \\
\text { - Back scratch } \\
\text { - Chair seat and reach } \\
\text { - } 6 \text {-minute walk test [m] } \\
\text { Muscle Strength of the Lower Extremities in } \\
\text { Isokinetic Conditions: } \\
\text { - Peak torque }\left(60^{\circ}\right) \text { flexors } \\
\text { - Peak torque }\left(180^{\circ}\right) \text { flexors } \\
\text { - Peak torque }\left(300^{\circ}\right) \text { flexors } \\
\text { - Peak torque }\left(60^{\circ}\right) \text { extensors } \\
\text { - Peak torque }\left(180^{\circ}\right) \text { extensors } \\
\text { - Peak torque }\left(300^{\circ}\right) \text { extensors }\end{array}$ & $\begin{array}{l}\text { Drop-outs (n): } 8 \text { women } \\
\text { Rate: } 40 \% \\
\text { Adverse effects: NR } \\
\text { Significant differences: } \\
\text { - Intra-group (pre-post): } \\
\text { - Eight foot up and go [s] } \\
\text { - Arm curl [Reps] } \\
\text { - Chair stand [Reps] } \\
\text { - Back scratch [cm] } \\
\text { - Chair seat and reach [cm] } \\
\text { - 6-minute walk test [m] } \\
\text { - Peak torque flexors: } \\
\text { - 60/s: } \text { Right* }^{*} \\
\text { - 180/s:Right* left* } \\
\text { - 300/s:left } \\
\text { - Peak torque extensors: } \\
\text { - 60/s: right** } \\
\text { - 180/s:right** } \\
\text { - 300/s:right** left* }\end{array}$ \\
\hline $\begin{array}{l}\text { Petchter et al. } \\
2003 a^{3}\end{array}$ & $\begin{array}{l}\text { The study objective was to } \\
\text { determine the effectiveness } \\
\text { of } 12 \text { weeks of regular } \\
\text { aquatic exercise, training the } \\
\text { cardiorespiratory resistance } \\
\text { and functional parameters in } \\
\text { patients with chronic renal } \\
\text { failure }\end{array}$ & $\begin{array}{l}\text { Sample ( } n \text {; } \% \text { men/women): } \\
n=20 \\
\text { (IG: } n: 11.66 \% \text { men, } 33 \% \\
\text { women) } \\
\text { (CG (control group): } n: 9.66 .7 \% \\
\text { men, } 32.3 \% \text { women) } \\
\text { Distribution and age: } \\
\text { IG: } 45 \pm 3.5 \text { years ( } 6 \text { men and } 5 \\
\text { women ( } n=11 \text { ) } \\
\text { (CG: } 47.9 \pm 3.8 \text { years ( } 6 \text { men } \\
\text { and } 3 \text { women ( } n=9 \text { ) } \\
\text { T diagnosed (years): } \mathrm{NI}\end{array}$ & $\begin{array}{l}\text { Duration: } 12 \text { weeks } \\
\text { IG: Frequency: } 2 \text { day/week } \\
\text { Duration: } 30 \text { min. } \\
\text { Type of exercise: Aquatic } \\
\text { exercise. } \\
\text { Intensity: } 40-50 \% \text { of } \mathrm{VO}_{2} \text { max } \\
\text { CG: maintain normal activity. }\end{array}$ & $\begin{array}{l}\text { Physical condition: } \\
\text { - } \mathrm{V}_{2} \text { max } \\
\text { - BMI } \\
\text { Biochemical and/or haematological } \\
\text { - Cysteine C } \\
\text { - Glomerular filtration rate } \\
\text { - Proteinuria } \\
\text { - Blood pressure }\end{array}$ & $\begin{array}{l}\text { Drop-outs (n): } 0 \\
\text { Rate: } 0 \% \\
\text { Adverse effects: NE } \\
\text { Significant differences: } \\
\text { Intervention group: } \\
\text { - V02max* } \\
\text { - SBP ** } \\
\text { - DBP* } \\
\text { - UProtV** } \\
\text { - CysC * }\end{array}$ \\
\hline $\begin{array}{l}\text { Petchter et al. } \\
2014^{28}\end{array}$ & $\begin{array}{l}\text { The study objective was to } \\
\text { analyse the association of } 10 \\
\text { years of regularly performed } \\
\text { aquatic exercise with the } \\
\text { study endpoint, all-cause } \\
\text { death or start of dialysis. }\end{array}$ & $\begin{array}{l}\text { Sample ( } \mathrm{n} \text {; \%men/women): } \\
n=16 \\
\text { (IG: } \mathrm{n}: 3 \% 42.9 \text { men } \\
457.1 \% \text { women.) } \\
\text { (CG: } \mathrm{n}=6, \% 66.7 \text { men, } \\
3,32.3 \% \text { women) } \\
\text { Distribution and age: } \\
\text { IG: } 47 \pm 16 \text { years } \\
\text { CG: } 50 \pm 15 \\
\text { T diagnosed (years): } \mathrm{NI}\end{array}$ & $\begin{array}{l}\text { Duration: } 12 \text { weeks } \\
\text { IG: Frequency: } 2 \text { day/week } \\
\text { Duration: } 30 \text { min. Type of } \\
\text { exercise: Aquatic exercise. } \\
\text { Intensity: } 40-50 \% \text { of V02max } \\
\text { CG: maintain its normal } \\
\text { activity. }\end{array}$ & $\begin{array}{l}\text { Biochemical and/or haematological } \\
\text { - Glomerular filtration rate } \\
\text { - Proteinuria }\end{array}$ & $\begin{array}{l}\text { Drop-outs (n): } 10 \\
\text { Rate: } 35.6 \% \\
\text { Adverse effects: NR } \\
\text { Significant differences: NR }\end{array}$ \\
\hline
\end{tabular}




\begin{tabular}{|c|c|c|c|c|c|}
\hline Authors (year) & Objective & Participants & Intervention & Variables (test) & Significant results $(p<0.05)$. \\
\hline $\begin{array}{l}\text { Anastasia et al. } \\
2015^{29}\end{array}$ & $\begin{array}{l}\text { The study objective was } \\
\text { to assess the effects of an } \\
\text { aquatic programme on the } \\
\text { functional capacity and } \\
\text { quality of life of patients on } \\
\text { haemodialysis. }\end{array}$ & $\begin{array}{l}\text { Sample ( } \mathrm{n} ; \% \text { men/women): } \\
n=27 \\
\text { (IG: } n=15,86.67 \% \\
\text { men } 13, \% 13.33 \text { women } 2 \text { ) } \\
\text { (CG: } n=12,91.67 \% \\
\text { men } 11,8.33 \% \text { women } 1 \text { ) } \\
\text { Distribution and age: } \\
\text { IG: } 48.0 \pm 11.3 \\
\text { CG: } 48.6 \pm 15.4 \\
\text { Tdiagnosed (years): } \\
0.25>\text { years minimum. }\end{array}$ & $\begin{array}{l}\text { Duration: } 16 \text { weeks } \\
\text { IG: Frequency: } 3 \text { day/week } \\
\text { Duration: } 60 \text { min. Type of } \\
\text { exercise: Aquatic exercise. } \\
\text { Intensity: Borg Scale of } \\
\text { Perceived Exertion (6-20) with } \\
\text { effort 40-50\% of V0 max } \\
\text { CG: maintain normal activity. }\end{array}$ & $\begin{array}{l}\text { Physical fitness assessment-exercise testing } \\
-6 \text { min walk test(m) } \\
\text { - Sit to stand (s) } \\
\text { - Handgrip (kg) } \\
\text { - Sit and reach (cm) } \\
\text { - Timed up and go } \\
\text { - (s) } \\
\text { Health-related quality of life assessment. } \\
\text { - Short Form-36 Questionnaire }\end{array}$ &  \\
\hline $\begin{array}{l}\text { Petchter et al. } \\
2003^{31}\end{array}$ & $\begin{array}{l}\text { The study objective was to } \\
\text { determine whether a regular } \\
\text { aquatic programme with } \\
12 \text { weeks of low intensity } \\
\text { exercise could have an } \\
\text { improving effect on patients } \\
\text { with moderate CRF and to } \\
\text { compare the outcome with } \\
\text { data from the sedentary } \\
\text { control group. }\end{array}$ & $\begin{array}{l}\text { Sample ( } \mathrm{n} ; \% \text { men/women): } \\
n=26 \\
\text { (IG: } n=17,41.2 \% \\
\text { men } 7,58.8 \% \\
\text { women10)(CG: } n=9,6,66.7 \% \\
\text { MEN , 3,33.3\% WOMEN) } \\
\text { Distribution and age: } \\
\text { IG: } 50 \pm 15 \text { years } \\
\text { CG: } 51.5 \pm 20.5 \text { years } \\
\text { T diagnosed (years): } \\
\mathrm{NI}\end{array}$ & $\begin{array}{l}\text { Duration: } 12 \text { weeks } \\
\text { IG: Frequency: } 2 \text { day/week } \\
\text { Duration: } 30 \text { min. Type of } \\
\text { exercise: Aquatic exercise. } \\
\text { Intensity: } 40-50 \% \text { of } \text { VO }_{2} \text { max } \\
\text { CG: NE }\end{array}$ & $\begin{array}{l}\text { Physical condition: } \\
\text { - } 0_{2} \text { max } \\
\text { - BMI } \\
\text { Biochemical and/or haematological } \\
\text { - Cystatin-C } \\
\text { - Glomerular filtration rate } \\
\text { - Proteinuria } \\
\text { - Blood pressure }\end{array}$ & $\begin{array}{l}\text { Drop-outs (n): } 0 \\
\text { Rate: } 0 \\
\text { Adverse effects: NR } \\
\text { Significant differences: } \\
\text { Intervention group: } \\
\text { - Peak 02 pulse* } \\
\text { - Peak ventilation* } \\
\text { - Peak load* } \\
\text { - Cys-C* } \\
\text { - U-Prot* } \\
\text { - SBP* } \\
\text { - DBP* } \\
\text { - LPO* }\end{array}$ \\
\hline
\end{tabular}

\section{Discussion}

In this investigation, the evidence of the effectiveness of physical exercise programmes in an aquatic environment as a strategy to improve the physical condition of patients with CKD was examined and critically reviewed. It is important to emphasise that, in addition to randomised clinical trials, this study also included other trials. This was done for the following reasons. Firstly, the lack of studies that lead to a substantiated conclusion. It was therefore decided to include in this investigation articles that were not randomised clinical trials in order to obtain a more general view of the evidence available and to report it for future scientific investigations ${ }^{33}$. Secondly, the inclusion of more studies gives greater robustness to the meta-analyses conducted, making it possible to substantiate each statistical test with better judgement ${ }^{27}$.
Although a limited number of investigations were located and their methodological quality was poor, it was still possible to extract important information that can be used for future studies.

After presenting the data on exercise programmes in an aquatic environment in this review, it can be said that these programmes had a beneficial and significant impact on the physical condition parameters (strength in lower limbs, stability), physiological parameters (cardiorespiratory capacity, renal function, diastolic pressure, systolic pressure) as well as emotional parameters (quality of life) for persons with CKD. Generally speaking, the results of the meta-analyses give greater weight to the benefits of this aquatic environment to those suffering from this disease. The effects of these aquatic programmes indicate that the physical condition, the physiology together with the patient's state of mind, can improve significantly more than with other physical exercise programmes. 
Figure 3. Meta-analysis - physical condition variables.

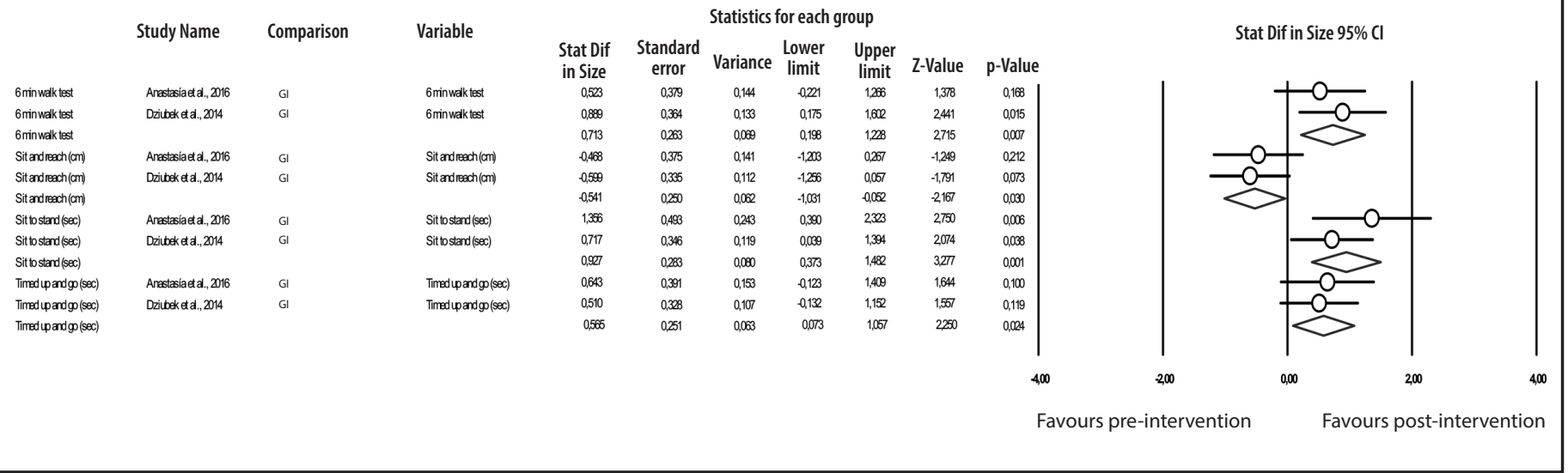

Likewise, it should be emphasised that, in the course of these aquatic exercise programmes, no drop-outs or adverse effects were reported. In land-based programmes, the principal cause of drop-out or the failure to complete the programmes is a lack of physical strength ${ }^{19}$, making it difficult for patients to continue the study, giving even more support to studies in an aquatic environment. Those suffering from CKD may have a poor quality of life, making it difficult to attend programmes to improve their physical condition. With regard to this, it should be pointed out that complete attendance in the studies shows a high frequency (91.6\%). These results make it more feasible to propose interventions in an aquatic environment as the way to improve physical condition. Moreover, diseases such as arthrosis, diabetes mellitus or Parkinson's, have found benefits in aquatic exercise ${ }^{19,20,34}$. Finally, it should be highlighted that these patients come with quality of life problems that affect the disease. In this review, only one study ${ }^{29}$, made an investigation to show the results with regard to the quality of life of these patients. Although the study considers a number of variables for these patients, both emotional and physical, these are insufficient to provide clear and accurate information to the review. This therefore represents an opportunity to conduct a more detailed study on the exercise programmes and the quality of life of patients suffering from this disease in order to consider the potential benefits that this could bring.

The study is not without limitations. Firstly, the methodological quality of the studies was poor, requiring better quality in order to conduct a more accurate investigation, indicating that future investigations should be made. Secondly, although the statistical tests show a positive correlation, men and women are included within the sample, forming a non-heterogeneous group. Furthermore, the groups in the studies do not contain the same sample for each group, giving more weight to one study compared to another. Thirdly, considering the limited number of studies included in the meta-analysis and its high heterogeneity, the assertions made in the study must be taken with caution, given the limitation in the application of the statistical tests in the actual studies analysed and in the meta-analysis subsequently conducted in this article.

\section{Conclusion}

The results of this review indicate that aquatic exercise is a safe and feasible option for persons with CKD. Although there is limited scientific evidence with regard to its benefits, doing aquatic exercise could improve the physical health of patients. However, further studies on this subject are necessary, particularly those focussing on the impact of this type of physical therapy.

\section{Conflict of interests}

The authors have no conflict of interest at all.

\section{Bibliography}

1. Eknoyan G, Lameire N, Eckardt K, Kasiske B, Wheeler D, Levin A, et al. KDIGO 2012 clinical practice guideline for the evaluation and management of chronic kidney disease. Kidney Int. 2013;3:1-150.

2. Chronic Kidney Disease Prognosis Consortium. Association of estimated glomerular filtration rate and albuminuria with all-cause and cardiovascular mortality in general population cohorts: a collaborative meta-analysis. Lancet. 2010;375:2073-81.

3. Otero A, de Francisco A, Gayoso P, Garcia F. Prevalence of chronic renal disease in Spain: results of the EPIRCE study. Nefrologia. 2010;30:78-86.

4. Cabrera SS. Definición y clasificación de los estadios de la enfermedad renal crónica. Prevalencia. Claves para el diagnóstico precoz. Factores de riesgo de enfermedad renal crónica. Nefrologia. 2004;24:27-34.

5. Alcázar Arroyo R, Orte L, González Parra E, Górriz JL, Navarro JF, Martín de Francisco $A L$, et al. Documento de consenso SEN-semFYC sobre la enfermedad renal crónica. Nefrologia. 2008;28:273-82.

6. Arrieta J, Rodríguez-Carmona A, Remón C, Pérez-Fontán M, Ortega F, Sánchez Tornero JA, et al. La diálisis peritoneal es la mejor alternativa coste-efectiva para la sostenibilidad del tratamiento con diálisis. Nefrologia. 2011;31:505-13.

7. Cunha Franco L, Teles Zatta L, Vasconcelos P, Alves Barbosa M, Santana dos Santos JR, De Oliveira Rosa L. Evaluación de la calidad de vida de pacientes de insuficiencia renal crónica en diálisis renal. Enferm Global. 2011;10:158-64.

8. Seguí Gomà A, Amador P, Ramos Alcario AB. Calidad de vida en pacientes con insuficiencia renal crónica en tratamiento con diálisis. Rev Soc Esp Enferm Nefrol. 2010;13:155-60 
9. Torregrosa JV, Bover J, Cannata Andía J, Lorenzo V, de Francisco ALM, Martínez I, et al. Recomendaciones de la Sociedad Española de Nefrología para el manejo de las alteraciones del metabolismo óseo-mineral en los pacientes con enfermedad renal crónica (SEN-MM). Nefrologia. 2011;31:3-32.

10. Salvador González B, Rodríguez Rascual M, Ruipérez Guijarro L, Ferré González A, Cunillera Puertolas O, Rodríguez Latre LM. Enfermedad renal crónica en Atención Primaria: prevalencia y factores de riesgo asociados. Aten Primaria. 2015:47:236-45.

11. Guzmán K, Fernández de Córdoba J, Mora F, Vintimilla J. Prevalencia y factores asociados a enfermedad renal crónica. Rev Med Hosp Gen Mex. 2014;77:108-13.

12. Junqué Jiménez A, Esteve Simó V, Tomás Bernaveu E, Paz Lopez O, Iza Pinedo G, Luceño Solé l, et al. Resultado de un programa adaptado de ejercicio físico en pacientes ancianos en hemodiálisis. Enferm Nefrol. 2015;18:11-18.

13. Fayad Saeta S, Escalona Labaceno R, Feraud Temó G. El ejercicio físico en el tratamiento del enfermo con insuficiencia renal crónica (IRC). Cuadernos de Psicología del Deporte. 2005;5:49-66.

14. Beddhu S, Baird B, Zitterkoph J, Neilson J, Greene T. Physical Activity and Mortality in Chronic Kidney Disease (NHANES III). Clin J Am Soc Nephrol. 2009;4:1901-6.

15. Padilla J, Krasnoff J, Da Silva M, Hsu CY, Frasseto L, Johansen KL, et al. Physical functioning in patients with chronic kidney disease. J Nephrol. 2008; 21:550-9.

16. Kosmadakis G, Bevigton A, Smith AC, Clap EL, Viana JL, Bishop NC, et al. Physical exercise in patients with severe kidney disease. Nephron Clin Pract. 2010;115:7-16.

17. Barcellos F, Santos I, Umpierre D, Bohkle M, Halla P. Effects of exercise in the whole spectrum of chronic kidney disease: a systematic review. Clin Kidney J. 2015;8:753-65.

18. Van Vilsteren $M$, de Greef $M H$, Huisman RM. The effects of a low-to-moderate intensity pre-conditioning exercise program linked with exercise counselling for sedentary hemodialysis patients in The Netherlands: results of a randomized clinical trial. Nephrol Dial Transplant. 2005:20:141-6.

19. Moreno JA, Galindo C, González-Cutre D, Marcos P. Perfiles motivacionales de practicantes en el medio acuático frente al medio terrestre. Rev Int Med Cienc Act Fís Dep. 2009;9:201-16.

20. Pérez-de la Cruz S, García Luengo AV, Lambeck J. Efectos de un programa de prevención de caídas con Ai Chi acuático en pacientes diagnosticados de párkinson. Neurología. 2016;31:176-82.

21. Moher $D$, Shamseer $L$, Clarke $M$, Ghersi $D$, Liberati $A$, Petticrew $M$, et al. Preferred reporting items for systematic review and meta-analysis protocols (PRISMA-P) 2015 statement. Syst Rev. 2015;1:1-9.
22. De Morton NA. The PEDro scale is a valid measure of the methodological quality of clinical trials: a demographic study. Aust J Physiother. 2009;55:129-33.

23. Paci, M, Matulli, G, Baccini, M, Rinaldi, LA, Baldassi, S. Reported quality of randomized controlled trials in neglect rehabilitation. Neuro/ Sci. 2010;31: 159-63.

24. Slim K, Forestier D, Kwiatkowski F, Panis Y, Chipponi J. Methodological index for nonrandomized studies (MINORS): Development and validation of a new instrument. Anz J Surg. 2003;73:712-6.

25. Slade S, Dionne C, Underwood C, Buchbinder R. Consensus on Exercise Reporting Template (CERT): explanation and elaboration statement. Br J Sports Med. 2016;50: 1428-37.

26. Higgins JPT, Altman DG, Gøtzsche PC, Jüni P, Moher D, Oxman AD, et al. The Cochrane Collaboration's tool for assessing risk of bias in randomized trials. BMJ. 2011;201:1-9.

27. Tufanaru, C., Munn, Z., Stephenson, M., Aromataris, E. Fixed or random effects metaanalysis? Common methodological issues in systematic reviews of effectiveness. Int J Evid Based Healthc. 2015;13:196-207

28. Pechter Ü, Raagb M, Ots-Rosenberga M. Regular aquatic exercise for chronic kidney disease patients: a 10-year follow-up study. Int J Rehabil Res.2014; 37:251-5.

29. Samara A, Kouidi E, Fountoulakis K, Alexiou S, Deligiannis A. The effects of aquatic exercise on functional capacity and health-related quality of life in hemodialysis patients. J Clin Exp Nephrol. 2016:1-6.

30. Pechter Ü Ots M, Mesikepp S, Zilmer K, Kullissaar T, Vihalemm T, et al Beneficial effects of water-based exercise in patients with chronic kidney disease. Int J Rehabi Res.2003;26:153-6.

31. Pechter Ü, Maaroos J, Mesikepp S, Veraksits A, Ots M. Regular low-intensity aquatic exercise improves cardio-respiratory functional capacity and reduces proteinuria in chronic renal failure patients. Nephrol Dial Transplant. 2003;3:624-5.

32. Dziubek W, Bulińska K, Rogowski L, Goleobiowski T, Kusztal M, Grochola M, et al. The effects of aquatic exercises on physical fitness and muscle function in dialysis patients. Biomed Res Int. 2015;2015:1-9.

33. Linde K, Scholz M, Melchart D, Willich SN. Should systematic reviews include nonrandomized and uncontrolled studies? The case of acupuncture for chronic headache. J Clin Epidemiol. 2002:55:77-85.

34. McNamara R, McKeough Z, McKenzie D, Alison J. Water-based exercise in COPD with physical comorbidities: a randomized controlled trial. Eur Respir J. 2013;41:1284-91. 